\title{
Resources and Capabilities Impact on Egyptian Travel Agencies' and Hotels ' Competitive Advantage: The mediating Role of Environmental Marketing Strategy.
}

\author{
EL-Hussein M. Ali \\ Raghda M. Badr \\ Faculty of Tourism and Hotels, Fayoum University
}

\begin{abstract}
The extremely dynamic and competitive environment of the tourism industry leads to the search for new methods and strategies to distinguish itself from its competitors. One of the primary trends in this sphere is environmental marketing strategy that can exploit all organizations' resources and capabilities. It can also use as a good strategy and an essential pillar for the development and sustainability of travel agencies, restaurants, catering firms, hotels and so on. The purpose of this study is to investigate the organizational resources and capabilities effect on sustainable competitive advantage through the mediating role of environmental marketing strategy within Egyptian travel agencies and hotels.

The present study is based on quantitative method to reach its aim. Data collection technique for the study is a structured questionnaire to collect data from 297 managers of five-star hotels and travel agencies (Category A) in Cairo which counted 33 hotels (Egyptian Hotel Guide, 2017) and 1267 travel agents (The Egyptian Travel Agents Association, 2017 and Egyptian Chamber of Tourism Establishments, 2017) to perceive their opinions on these resources and capabilities that lead to adopt an environmentally friendly strategic, and how this strategy affect competitive advantage. Statistical analyses were performed using the Statistical Package for Social Sciences (SPSS version 22) software. Results of study have been considered significant at $p \leq 0.05$. Systematic random sampling was used since the subjects were chosen due to their convenient accessibility and proximity. Data collection was carried out during the period from NovemberDecember 2019. The study has revealed very valuable results in the way it investigated the perceptions of managers on the role of organizational resources and capabilities which lead to build EMS. Meanwhile, this mediator factor of environmental marketing strategy showed a significant positive effect on agencies' and hotels' sustainable competitive advantage.

Keywords: Organizational Resources and Capabilities, Environmental Marketing Strategy,

Competitive Advantage, Managers, Travel Agencies, Hotels, Egypt.
\end{abstract} Introduction

According to Qoura and Ali, (2015) mentioned that tourism and hospitality industry became a distinct instrument for Egyptian national economic growth, because touristic activity generates incomes; it plays a pivotal role for other national branches, being a factor that attracts investments, increases job opportunities, and transforms local communities for the better (Botezat and Benea, 2012; Cheraghalizadeh and Tumer, 2017). But the heavy dependence on tourism has inevitably resulted in negative consequence on the natural environment, which led to air pollution, sea contamination, and uncontrollable regulation lack of ecosystems (Kousis, 2000; and Singjai et al., 2018). Therefore, many touristic organizations appear higher levels of environmentally proactive strategies and generally aim to reduce environmental aspects arising from their business and to enhance market-share; however, hotels and travel agencies can obtain additional benefits, for example, the improvement of their competitive advantages, image and reputation (Ottenbacher, 2007; Hall et al., 2010; and Fraj et al., 2015).

Tsai et al., (2009) cleared that there are highly significant changes are currently taking place in tourism field, with a notable increase in competition among tourism and hospitality establishments. Aragón-Correa and Rubio-Lopez, (2007) assured that the first result of this competitive environment is the need for these organizations to reconsider the distinct role of 
organizational resources and capabilities in promoting a good environmental marketing strategy, as well as the effect of this strategy on sustainable competitive advantage, which leads to increase the market-share of these organizations (Olavarrieta and Friedmann, 2008; Yasuo et al., 2010; Leonidou et al., 2013b; and Farias et al., 2014). In other words, these organizations must expand their perspectives beyond just an internal vision that aims to enhance their competitive position over other touristic organizations to include an external view where building and Consolidating relations with all stakeholders play a pivotal and important role in maintaining levels of attraction and profitability (Buysse and Verbeke, 2003; Menguc et al., 2010; McDonagh and Prothero, 2014; and Dzhangazova et al., 2015). Moreover, Consumers' preferences have switched toward more environmentally friendly goods and services (Kotler \& Lee, 2008; Fraj et al., 2015). Singjai et al., (2018) explained that this mission involves exploring, developing and maintaining organizational resources and capabilities along with some environmental factors enable companies to create a sustainable competitive advantage that will support its superior competitive position (Yu, 2011; and Camison and Fores, 2015). Creating this competitive advantage requires efficient management of the way these resources and capabilities are combined and the development of green strategies (Chiou et al., 2011; Bae, 2017; and Horng et al., 2017).

Day, (2014) showed that since the late 1980s, strategic issues related to the resource-based view and enterprise capabilities have attracted increasing attention in the marketing strategy literature (Kaleka, 2002; Gulati, 2010; and Yin-Hsi, 2012). So, the purpose of this research is to investigate the effect of organizational resources and capabilities on sustainable competitive advantage through the mediating role of environmental marketing strategy within Egyptian travel agencies and hotels.

\section{Literature review}

\section{Competitiveness and environmental issues: a theoretical perspective}

Papadas et al., (2019) asserted that environmental issues are increasingly recognized as a major concern for tourism industries worldwide (Robin et al., 2017). Singjai et al, (2018) agreed with Chiou et al., (2011) that there are many studies stress the importance of implementing an environmental strategy that could also lead to sustainable competitive advantage and profitability in the longer term (e.g. Leonidou et al., 2015a; Fraj et al., 2015; and Papadas et al., 2017). There is still a perceived but unresolved tension between green marketing and competitive advantage (El-Dief and Font, 2010; Leonidou et al., 2013a; Hsiao et al., 2014). Failure to follow a green marketing trend undermines global engagement with sustainable business practices, and exacerbates corporate risks and losses (Ottenbacher, 2007; Horng et al., 2017). According to Banerjee, (2017) and Papadas et al, (2019) despite the possibility costs involved, the harmful and costly environmental consequences of traditional linear production and consumption are driving more innovative solutions for firms to shift their focus to clean production, environmental design and eco-efficiency.

Ramanathan et al, (2016) indicated that some firms perform better than others by looking clearly at internal resources and capabilities as sources of sustainable competitive advantage. Some studies have used the firm's resource-based-view as an effective tool can create sustainable competitive advantage by environmental marketing strategy adoption (Tan et al., 2007; AragonCorrea et al., 2008; Leonidou et al., 2013a). 


\section{Green Dimensions in the tourism and hospitality industry}

Leonidou et al, (2013b) agreed with Kasim, (2009) stated that green dimensions in the hotels and travel agencies have taken different directions; some of these organizations look at environmental issues based on their environmental knowledge, attitudes and behavior "KAP model" that can be categorized into unconvinced minor participants, anti-green pragmatists, or committed actors to green practices (Dewhurst and Thomas, 2003; Tzschentke et al., 2008). While some other hotels and agencies canters on the factors driving the adoption of eco-friendly behavior that grouped in (more sales, profits, competitive advantages, market-share and ethical motives to green practices) or the factors preventing the adoption of eco-friendly behavior, which may be represented in a lack of infrastructural, the additional costs associated with taking environmental measures, lack of internal resources and operational barriers to green practices (Doody, 2010; Lopez-Gamero et al., 2011a; Chan, 2011, Garay and Font, 2012). Other group of firms deal with green issues through planning such as environmentalists use, or operation processes like water conservation, energy savings, air pollution control, and waste management (Erdogan and Baris, 2007; Bohdanowicz et al., 2011; Ball and Taleb, 2011). Furthermore, El Dief and Font, (2010) declared that many other hotels and agencies turned to environmental issues through green marketing. In addition, Hudson and Miller, (2005) identified four potential strategic situations towards environmental marketing concerns represented into inactive situation that finds no benefit in allocating resources to eco-friendly activities; or reactive situation that is finding engagement in environmental issues beneficial but failing to communicate this effort; and exploitative situation that exploits consumer interest in eco-friendly products without considering resource characteristics, environmental ethics, or long term perspectives; finally proactive situation which is adopting a strong commitment toward protecting the environment and actively communicating eco-friendly behavior (Hsieh, 2012; and Leonidou et al., 2013a).

To investigate the effect of organizational resources and capabilities on sustainable competitive advantage through the mediating role of environmental marketing strategy within Egyptian travel agencies and hotels, we develop a conceptual framework consisting of two sets of constructs. The first one depends on the impact of organizational resources (i.e., physical, financial, and experiential) and capabilities (i.e., shared vision, relationship building, and technology sensing/response) on green marketing strategy adoption. The second set represented in the impact of green marketing strategy adoption that comprising product/service, price, distribution, promotion, people, atmosphere, and processes on the creation of a sustainable competitive advantage.

\section{Organizational Resources and Capabilities}

Lopez-Gamero et al., (2011b) mentioned that organizational resources and capabilities should to be source of sustainable competitive advantage, which relies on the deployment of valuable, rare, and costly resources and capabilities to imitate (Ray et al., 2004; Wang and Ahmed, 2007). However, a sustainable competitive advantage may not last forever, because unexpected changes in the economic structure of the service industry (e.g., entry of new competitors) may minimize the value of a particular resource and capability and thus reduce its contribution as a source of competitive advantage (Kaleka, 2002; Leonidou et al., 2013b). To reach the full competitive potential of its resources and capabilities, the firm must develop environmental marketing strategies that implement a long-term vision using its business processes effectively and efficiently (Clarkson et al., 2011; Buysse and Verbeke, 2003; Darnall, and Edwards, 2006).

Hart and Dowell, (2011) determined that resources include tangible and intangible assets that are permanently associated with the firm, such as physical, financial, and experiential. Regardless of 
their nature, resources are not produced alone, but must be assembled, integrated, and managed so that they form organizational capabilities (Newbert, 2008). Capabilities, in contrast, refer to the ability to achieve specific tasks with added value by using supportive resources to address external environments and meet changing market requirements and demands (e.g., technology sensing, shared vision, and relationship building) (Clarkson et al., 2011; Wang and Ahmed, 2007; Eisenhardt and Martin, 2000). In this highly competitive global market, these resources and capabilities are important to enable businesses to obtain and sustain their competitive advantage (Hart and Dowell, 2011; Garay and Font 2012).

Mol and Wijnberg, (2011) identified that there are three types of resources in the relevant literature that play a critical role in formulating eco-friendly marketing strategies (Nieves and Haller, 2014). Ferreira et al., (2018) agreed with Camisón and Forés, (2015) that the first type of resources is an experiential nature such as knowledge gained from the agencies' and hotel's operational experience, which helps identify and match customers' wants, needs and anticipate new market trends (Leonidou et al., 2015b; del Rosario et al., 2019). In contrast to tangible assets, experiential knowledge is an intangible resource that requires time to develop and accumulates through exposure to environmental practices of other hotels and agencies, internal environmental reviews, audits, information provided by advisory boards in the tourism and hospitality field, and other sources (Darnall \& Edwards, 2006; Shah, 2011; Camisón and Fores, 2015; Sánchez-Medina et al., 2016). Through the adoption of internal procedures and the accumulation of knowledge related to environmental issues, the firm Broadens and its experiential knowledge, which serves as a facilitator towards building eco-friendly marketing strategies (Kaleka, 2002; Galbreath, 2005; Dodd, 2016; Morgan et al., 2004). Leonidou et al., (2015b) indicated that the value of this experience will depend on the amount of time the hotels and agencies engage in environmental activities, the participation of managers in eco-friendly practices in their previous employment, and the involvement of the firm in a wider chain of hotels and agencies (Newbert, 2008; El Dief and Font, 2010; Guo et al., 2018). So, the researchers propose the following hypothesis:

H1: Travel agencies' and Hotels' experiential resources have a significant positive impact on developing an environmental marketing strategy.

Ramanathan et al., (2016) stated that the second type of organizational resources is financial resource, such as the agencies' and hotels' liquidity, working and other operational capital, and borrowing power, which are pivotal in achieving stability and success in eco-friendly marketing strategies (Bohdanowicz et al., 2011; Kasim et al., 2014; Horng et al., 2017). Dikova et al., (2017) found that investment in green issues and clean technologies include large amounts of expenses that require enough time before a satisfactory ratio of return is achieved, in addition to high risks associated with designing and supporting green strategies especially in high-growth industries such as tourism and hospitality sector, furthermore excessive operating costs resulting from supporting prices for some green products and services, setting up a reverse logistics mechanism, designing special green advertising campaigns, etc. (Kasim, 2009; Chan, 2011; and Ramanathan and Ramanathan, 2013). Indeed, financial resource restrictions are one of the main obstacles for hotels and travel agencies, especially smaller ones, to adopt environmental measures (Tzschentke et al., 2008; and Botezat and Benea, 2012). According to Evans, (2016) and Del Rosario et al, (2019) latest evidence also shows that travel agencies and hotels with a well financial position are more appropriate to be environmentally responsible than those that are financially sickly (Shah, 2011). Adequate financial resources are essential, not only in adopting the necessary green infrastructure in the organization but also in supporting a sustainable green 
marketing strategy (Greco et al, 2013; and Morgan et al, 2019). So, the researchers propose the following hypothesis:

H2: Travel agencies' and Hotels' financial resources have a significant positive impact on developing an environmental marketing strategy.

The third one is physical resources, that refers to use of recent technology equipment, tools and the accessibility of operating capacity or other infrastructure needed to ease product or service efficiency and effectiveness (Hall, 2006; Beleska-Spasova et al., 2012). Gil-Padilla and EspinoRodríguez, (2008) emphasized that If agencies and hotels completely deployed their resources can help them enrich and make better utility of its internal strategies concerned to environmental issues, such as waste reduction, energy conservation, environmentally friendly sources of supply, and pollution prevention (Cheraghalizadeh and Tumer, 2017). Bae, (2017) cleared that physical resources are also essential to support and sustain an eco-friendly marketing strategy as they help in building appropriate green products and services, processes, and infrastructure in the organization (Darnall and Edwards, 2006; Hart and Dowell, 2011; Leonidou et al., 2013b). So, the researchers propose the following hypothesis:

H3: Travel agencies' and Hotels' physical resources have a significant positive impact on developing an environmental marketing strategy.

Rodriguez-Diaz and Espino-Rodriguez, (2006) mentioned that there are three types of capabilities that affect an environmental marketing strategy. Ortega, (2010) showed that the first type of capabilities is technology sensing and sharing, which indicates the firm's ability to sense and quickly respond to new technologies (Rodriguez-Diaz \& Espino-Rodriguez, 2006; Wang et al., 2019). Gambardella and Giarratana, (2013) agreed with Leonidou et al., (2013b) that technology has the power to affect and transform business processes, products, and services, as well as assist environmental actions and form environmental marketing strategies (Gu and Jung, 2013; Welter et al., 2013). Neill et al., (2014) stated that with green technologies, we should consider their viability may be largely unknown, as well as the economic consequences of their use. In addition to these green technologies may cost a lot and suffer from low quality, especially when they are at the advanced stage (Leonidou et al., 2015a). However, hotels and agencies that can sense and respond to technological changes and advancements are more likely to be among the first to acknowledge the advantages of adopting green technologies such as energy savings, water conservation, waste management and product recycling and reuse (El Dief and Font, 2010; Wang et al., 2020). So, the researchers propose the following hypothesis:

H4: Travel agencies' and Hotels' technology sensing/response capability have a significant positive impact on developing an environmental marketing strategy.

The second type of organizational capabilities is shared vision, which is the presence of common ideas, commitment, and dedication among the hotel's and agency's employees toward the achievement of green organizational goals (Eisenhardt and Martin, 2000; and Camisón and Monfort 2012). Sharma et al., (2007) asserted that travel agencies and hotels with a shared vision are able to gather and organize the resources necessary to develop sustainable business practices, compared to firms that lack this capability (Bohdanowicz et al., 2011; Alt et al., 2014; Evans, 2015). So, the researchers propose the following hypothesis:

H5: Travel agencies' and Hotels' shared vision capability have a significant positive impact on developing an environmental marketing strategy.

Morgan et al., (2004) said that the third capability is relationship building that is, firms' ability to form fundamental and good relationships with their Stakeholders (Rodriguez-Diaz \& EspinoRodriguez, 2006; Leonidou et al., 2013b). Wang et al., (2019) emphasized that firms gain a better 
understanding and can respond better to their needs and wants and discover profitable market trends and opportunities through cooperation building (Singjai et al., 2018). Agencies and hotel customers, suppliers and other stakeholders concerning environmental issues is growing stronger and represents a critical force affecting firms to become environmentally behavior (Verreynne et al.,2016; Banerjee, 2017). As a result, firms with relationship-building capabilities are more able to recognize the attractiveness of environmentally friendly segments and understand the environmental requirements of different stakeholders in certain markets well in advance of the competition (Weerawardena and Mavondo, 2011). Solidifying links with various partners and responding to their ecological requests are particularly pivotal in the tourism and hospitality sector because they directly affect the level and nature of demand (Shaalan, 2005; Leonidou et al., 2015a). So, the researchers propose the following hypothesis:

H6: Travel agencies' and Hotels' relationship-building capability have a significant positive impact on developing an environmental marketing strategy.

\section{Environmental marketing strategy and competitive advantage}

Ong and Musa, (2012) and Kollmuss and Agyeman's (2002) defined environmentally-friendly behavior as "behavior consciously seeking to reduce the negative effect of one's actions on natural and build world', So, environmentally-friendly behavior refers to salespeople's act of recommending green agencies and hotels to their customers, such as supporting customers to stay at green hotels when traveling (Nisbet et al. 2009). According to Papadas et al., (2019) and Hudson and Miller, (2005) defined environmental marketing strategy as "the holistic management process responsible for determining, predicting and meeting the requirements of customers and local society, in a profitable and sustainable way".Leonido et al., (2013) informed that an environmental marketing strategy adoption should include product and service, price, distribution, promotion, people, atmosphere, and processes on the forming of a sustainable competitive advantage. Papadas et al., (2017) cleared that product and Service refer to use of eco-friendly supplies and gives priority to offering ecological products and services (Greco et al., 2013). Royne et al., (2011) indicated that price is represented in building environmental compliance costs in the service price, to offer better and competitive prices as a result of the environmentally friendly practices implemented (Ren et al., 2015). Lopez-Gamero et al., (2011a) showed that distribution refers to show priority for suppliers and strategic partners which embrace environmental responsibility (Vorhies and Morgan, 2005; O'Cass and Weerawardena, 2010). El Dief and Font, (2010) declared that promotion should highlight firm's commitment to environmental preservation in its advertisements, sponsorships, and campaigns. Morgan et al., (2019) agreed with Ramanathan et al., (2016) that employees should be encouraged to actively participate in environmental awareness programs and activities organized for the community. Agencies and hotels seek to use renewable sources of energy and water saving practices in public areas and guests' rooms, in addition to waste management practices (Sánchez-Medina et al., 2016; and Papadas et al., 2019). Travel agencies and hotels should cooperate with customers, local communities, and governmental agencies to enhance environmental standards and practices through their various processes (Kasim, 2009; Hsiao et al., 2014; Shah, 2011).

McDonagh and Prothero, (2014) emphasized that spreading knowledge and setting an environmental culture throughout the organization encourages employees to develop skills and abilities to implement successful environmental strategies (Ramanathan et al, 2016). Morgan et al., (2012) indicated that organizations should align their green marketing strategy with the behavior of their employees who are expected to serve and implement it (Papadas et al, 2017). Leonidou et al., (2013b) asserted that these green marketing strategies can help organizations to 
reduce long run costs and determine their offerings from those of their competition, as a result of cheaper recyclable materials use, energy-saving processes, waste-minimization solutions, and operating process improvements (Ramaswami et al, 2009; Weerawardena and Mavondo, 2011). According to Menguc et al., (2010) and Royne et al., (2011) that customers are willing to pay higher prices for environmentally friendly products and services. In addition, organizations can improve their current processes, product, and services quality by making them greener (Singjai et al., 2018; and Guo et al., 2018). These whole benefits make hotels and agencies more attractive, likable, favourable and acceptable offering to customers than that of the competition (Chiou et al., 2011; Delmas et al., 2011; Fraj et al., 2015). In other words, Banerjee, (2017) agreed with El Dief and Font, (2010) that adopting environmentally friendly strategies in hotels lead to create a sustainable competitive advantage (Papadas et al., 2017). So, the researchers propose the following hypothesis:

H7: The adoption of an environmental marketing strategy has a significant positive impact on the hotel and travel agency competitive advantage.

\section{Research method}

\section{Conceptual Framework and Hypotheses Development}

The research framework aims to explain the study variables (see Figure 1), by illustrating that the organizational resources and capabilities play a pivotal role in implementing environmental marketing strategy, and how this strategy affects Egyptian hotels' and travel agencies' competitive advantage. Therefore, organizational resources and capabilities have a significant positive effect on Egyptian hotels' and travel agencies' competitive advantage. The aforementioned explanations serve as a literature base, much needed in order to complete this research and test the following seven hypotheses:

H1: Travel agencies' and Hotels' experiential resources have a significant positive impact on developing an environmental marketing strategy.

H2: Travel agencies' and Hotels' financial resources have a significant positive impact on developing an environmental marketing strategy.

H3: Travel agencies' and Hotels' physical resources have a significant positive impact on developing an environmental marketing strategy.

H4: Travel agencies' and Hotels' technology sensing/response capability have a significant positive impact on developing an environmental marketing strategy.

H5: Travel agencies' and Hotels' shared vision capability have a significant positive impact on developing an environmental marketing strategy.

H6: Travel agencies' and Hotels' relationship-building capability have a significant positive impact on developing an environmental marketing strategy.

H7: The adoption of an environmental marketing strategy has a significant positive impact on the hotel and travel agency competitive advantage. 
Fig.1: Conceptual framework of organizational resources and capabilities impact on competitive advantage through the mediating role of environmental marketing strategy

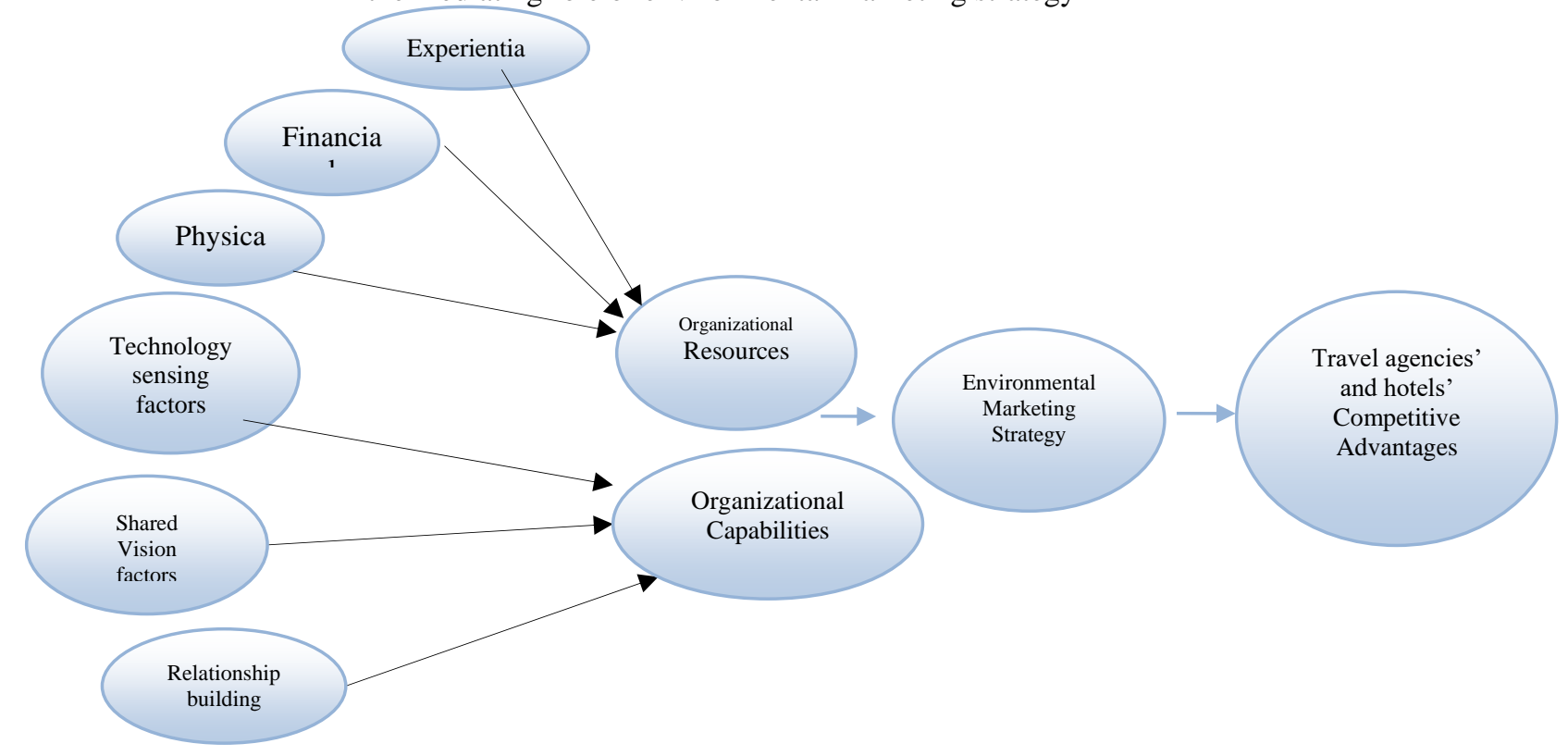

This study is based on a quantitative approach to achieve its aim. The primary data was collected through a structured questionnaire from 297 managers of five-star hotels and travel agencies (Category A) in Cairo which counted 33 hotels (Egyptian Hotel Guide, 2017) and 1267 travel agents (The Egyptian Travel Agents Association, 2017 and Egyptian Chamber of Tourism Establishments, 2017). Statistical analyses were performed using Statistical Package for Social Sciences (SPSS version 22) software. Results of study have been considered significant at $\mathrm{p} \leq$ 0.05. Systematic random sampling was employed to collect data from hotels' and travel agencies' managers located in Cairo who counted 1300. So, sample size was calculated according to the following formula:

$\mathrm{N}=$ Study Population $=1300$

$\mathrm{Z}=0.95=1.96$

$\mathrm{d}=0.05$

$n=\frac{N \times p(1-p)}{\left.\left[\| N-1 \times\left(d^{2} \div z^{2}\right)\right]+p(1-p)\right]}$

$\mathrm{p}=0.50$

$\mathrm{n}=297$

The sample size formula revealed a number of 297 mangers as a sample size. The questionnaire forms were distributed and collected from the investigated sample during period from November - December 2019. The study has tested seven hypotheses of how organizational resources and capabilities affecting the mediating variable (environmental marketing strategy) and how this strategy affects Egyptian hotels' and travel agencies' competitive advantage.

\section{The Questionnaire}

Data for this study were gathered using a structured questionnaire with a 5-point Likert-style scale (" $1=$ strongly disagree" to "5=strongly agree"). Questionnaire items were adapted from previous studies (i.e., Leonidou et al., 2013; Kasim et al., 2014; Leonidou et al., 2015; Ramanathan et al., 2016; Cheraghalizadeh and Tumer, 2017; Ferreira et al., 2018; and del Rosario et al., 2019 scales for financial, experiential, and physical resources), while the scales for technology sharing, relationship building, and shared vision were extracted from the studies of Ortega, 2010; Alt et al., 2014; Evans, 2015; Banerjee, 2017; Wang et al., 2020. Whereas 
elements of environmental marketing strategy whose scales came from (Ong and Musa, 2012; Ren et al., 2015; Papadas et al., 2019). Finally, the competitive advantage scale derived from (Fraj et al., 2015; Singjai et al., 2018; Guo et al., 2018).

45 items were used to measure the eight constructs of the hypothesized model: 'physical' (measured by 3 items), 'financial' (3 items), 'experiential' (3 items), 'technology sensing' (3 items), 'relationship building' (3 items), 'shared vision' (3items), 'elements of environmental marketing strategy' (21 items), and 'hotels' and agencies' competitive advantage' (6 items). Personal data were also included in the form (i.e., gender, Age, education level, and Nationality). Frequencies, means, standard deviation, regression and percentages were calculated. Then, Multiple Linear Regression was used to determine how groups differed significantly from each other.

The questionnaire was pre-tested with 15 hotels' and agencies' managers, and six academic experts in the field, resulting in minor adjustments regarding vocabulary and design to improve flow, clarity, and validity. Reliability of constructs was tested by running Cronbach's alpha coefficient. It was computed and exceeded 0.70 for all constructs reflecting reliable results (Hair et al., 2010).

Table 1: Cronbach's alpha of organizational resources and capabilities, environmental marketing strategy and agencies' and hotels' competitive advantage

\begin{tabular}{|l|c|c|c|}
\hline \multicolumn{1}{|c|}{ Variables } & Question numbers & No. of Items selected & Cronbach's Alpha \\
\hline Experiential Resources & $1-3$ & 3 & .710 \\
\hline Financial Resources & $4-6$ & 3 & .774 \\
\hline Physical Resources & $7-9$ & 3 & .783 \\
\hline Technology Sensing Capability & $10-12$ & 3 & .801 \\
\hline Shared Vision Capability & $13-15$ & 3 & .822 \\
\hline Relationship building Capability & $16-18$ & 3 & .751 \\
\hline Environmental Marketing Strategy & $19-39$ & 21 & .741 \\
\hline Competitive Advantages & $40-45$ & 6 & .825 \\
\hline
\end{tabular}

The table above shows that Experiential Resources had the least value $(\alpha=0.710)$, followed by

Financial Resources with a reliability value of $(\alpha=0.774)$, then Physical Resources had the reliability value of $(\alpha=0.783)$, Technology Sensing Capability had a reliability value of $(\alpha=$ $0.801)$, Shared Vision Capability had a reliability value of $(\alpha=0.822)$, Relationship building Capability had a reliability value of $(\alpha=0.751)$, while Environmental Marketing Strategy had a reliability value of $(\alpha=0.741)$. Competitive Advantages of travel agencies and five-star hotels the highest reliability value of $(\alpha=0.825)$.

\section{Results and discussion}

\section{Questionnaire Response Rate}

The current study targeted managers of travel agencies "category A" and five-star hotels in Cairo as the structured questionnaire was sent to a convenient sample of 297 managers. A total of 263 usable were obtained with an average of $88.5 \%$ response rate.

\section{Descriptive Statistics of the Respondents}

The descriptive statistics showed that $96.5 \%$ of the respondents are males while $3.5 \%$ of them are females. $11 \%$ of the respondents are under 15years' experience, $73.4 \%$ of them are between $15-$ 20 years' experience, $15.6 \%$ are more than 20 years' experience. $80 \%$ had university level of education, $20 \%$ were Post-graduate study. 
Table 2: Descriptive statistics of the respondents $(n=263)$

\begin{tabular}{|c|l|c|c|}
\hline \multicolumn{2}{|l|}{ Description } & Frequency & \% \\
\hline \multirow{2}{*}{ Gender: } & Male & 254 & 96.5 \\
\cline { 2 - 4 } & Female & 9 & 3.5 \\
\hline \multirow{3}{*}{ Experience: } & Under 15 years & 29 & 11 \\
\cline { 2 - 4 } & 15 to 20 years & 193 & 73.4 \\
\cline { 2 - 4 } & More than 20 years & 41 & 15.6 \\
\hline \multirow{2}{*}{ Education level: } & Post-graduate study & 52 & 20 \\
\cline { 2 - 4 } & University education & 211 & 80 \\
\hline
\end{tabular}

Table 3 Descriptive Statists of Organizational Resources and Capabilities, Environmental Marketing Strategy and Agencies' and Hotels' competitive advantage.

\begin{tabular}{|l|c|c|c|}
\hline \multicolumn{1}{|c|}{ Factor/ Variable } & Mean & Std. Deviation & Attitude \\
\hline Experiential Resources & 4.01 & .831 & Agree \\
\hline Financial Resources & 4.63 & .984 & Strongly agree \\
\hline Physical Resources & 4.74 & .621 & Strongly agree \\
\hline Technology Sensing Capability & 4.24 & .747 & Strongly agree \\
\hline Shared Vision Capability & 4.82 & .941 & Strongly agree \\
\hline Relationship building Capability & 4.81 & .808 & Strongly agree \\
\hline Environmental Marketing Strategy & 4.17 & .535 & Agree \\
\hline Competitive Advantages & 4.53 & .691 & Strongly agree \\
\hline
\end{tabular}

The lowest mean of the independent variables was recorded in experiential resources which is 4.01, which indicates almost an "agree". Highest mean of 4.82 was recorded by relationship building Capability, which is almost a "Strongly Agree" level. This indicates how mangers rated all organizational resources and capabilities affecting the mediating variable (environmental marketing strategy adoption) and how this strategy affects Egyptian hotels' and travel agencies' competitive advantage.

Table 4: Spearman's correlation matrix among research variables

\begin{tabular}{|l|l|l|}
\hline \multicolumn{1}{|c|}{ Independent Variables } & \multicolumn{1}{c|}{ Correlation Coefficient } & \\
\hline \multirow{2}{*}{ Experiential Resources } & Spearman's Correlation & $.419^{* *}$ \\
\cline { 2 - 3 } Financial Resources & Sig. (2-tailed) & 0.003 \\
\hline \multirow{2}{*}{ Physical Resources } & Spearman's Correlation & $.728^{* *}$ \\
\cline { 2 - 3 } & Sig. (2-tailed) & 0.001 \\
\hline \multirow{2}{*}{ Technology Sensing Capability } & Spearman's Correlation & $.263^{* *}$ \\
\cline { 2 - 3 } & Sig. (2-tailed) & 0.007 \\
\hline \multirow{2}{*}{ Shared Vision Capability } & Spearman's Correlation & $.410^{* *}$ \\
\cline { 2 - 3 } & Sig. (2-tailed) & 0.004 \\
\hline \multirow{2}{*}{ Relationship building Capability } & Spearman's Correlation & $.392^{* *}$ \\
\cline { 2 - 3 } & Sig. (2-tailed) & 0.004 \\
\hline \multirow{2}{*}{ Environmental Marketing Strategy } & Spearman's Correlation & $.317 * *$ \\
\cline { 2 - 3 } & Sig. (2-tailed) & 0.009 \\
\hline \multirow{2}{*}{ Competitive Advantages } & Spearman's Correlation & $.739 * *$ \\
\cline { 2 - 3 } & Sig. (2-tailed) & 0.002 \\
\hline & Spearman's Correlation & $.296^{* *}$ \\
\cline { 2 - 3 } & Sig. (2-tailed) & 0.006 \\
\hline
\end{tabular}

** Correlation is significant at the 0.01 level (2-tailed). * Correlation is significant at the 0.05 level (2-tailed)

Correlation frequently measures the relationship among research variables. The objective of the study is to investigate the effect of organizational resources and capabilities on Competitive Advantage through the mediating role of environmental marketing strategy within Egyptian 
Travel Agencies and Hotels. In this study the level of significance is less than 1\% (99\% confidence). Therefore, $\mathrm{H} 0$ is rejected. According to above Table 4 indicates that there is a significant relationship among research variables. Coefficient of correlation of Experiential, Financial, Physical, Technology Sensing, Shared Vision, Relationship building, Environmental Marketing Strategy and Agencies' and Hotels' competitive advantage have recorded $0.419, .728, .263, .410, .392, .317,739$, and .296 , respectively. Researchers could see there is a positive association among organizational resources and capabilities, impact on adoption of environmental marketing strategy and improving and increasing agencies' and hotels' competitive advantage.

Table 5: Organizational resources and capabilities, environmental marketing strategy and agencies' and hotels' competitive advantage: regression analysis

\begin{tabular}{|c|c|c|c|c|c|c|c|}
\hline & \multirow[t]{2}{*}{ Model } & \multicolumn{2}{|c|}{$\begin{array}{l}\text { Unstandardized } \\
\text { Coefficients }\end{array}$} & \multirow[t]{2}{*}{$\mathbf{t}$} & \multirow[t]{2}{*}{ Sig. } & \multirow[t]{2}{*}{$\mathbf{R}^{2}$} & \multirow[t]{2}{*}{ Dependent Variable } \\
\hline & & B & Std. Error & & & & \\
\hline \multirow{7}{*}{1} & (Constant) & 1.234 & .235 & 4.629 & .000 & \multirow{7}{*}{0.701} & \multirow{7}{*}{$\begin{array}{c}\text { Environmental } \\
\text { Marketing Strategy }\end{array}$} \\
\hline & Experiential Resources & .107 & .112 & 2.121 & .007 & & \\
\hline & Financial Resources & .282 & .084 & 4.081 & .001 & & \\
\hline & Physical Resources & .744 & .012 & 2.016 & .003 & & \\
\hline & $\begin{array}{l}\text { Technology Sensing } \\
\text { Capability }\end{array}$ & .137 & .035 & 3.380 & .009 & & \\
\hline & Shared Vision Capability & .351 & .064 & 4.095 & .004 & & \\
\hline & $\begin{array}{l}\text { Relationship building } \\
\text { capability }\end{array}$ & .122 & .016 & 2.031 & .001 & & \\
\hline \multirow[b]{2}{*}{1} & (Constant) & 2.101 & 1.012 & 3.062 & .003 & \multirow[b]{2}{*}{0.513} & \multirow{2}{*}{$\begin{array}{c}\text { travel agencies' and } \\
\text { hotels' Competitive } \\
\text { Advantages }\end{array}$} \\
\hline & $\begin{array}{c}\text { Environmental Marketing } \\
\text { Strategy }\end{array}$ & .088 & .079 & 2.702 & .031 & & \\
\hline
\end{tabular}

The study results as shown in the table (5) and figure (1) revealed that organizational resources and capabilities play a pivotal role in implementing environmental marketing strategy, and how this this strategy affects Egyptian hotels' and travel agencies' competitive advantage. Therefore, organizational resources and capabilities have a significant positive effect on Egyptian hotels' and travel agencies' competitive advantage. This agreed with that mentioned by Singjai et al, (2018) and Papadas et al., (2019) who emphasised that organizations can improve their current processes, product and services quality by making them greener, and these motives make travel agencies and hotels to be more attractive, likable, favourable and acceptable offering to customers than that of the competition. In other words Leonidou et al., (2013b) agreed with Fraj et al., (2015) that adopting an environmentally friendly strategic in firms lead to create a competitive advantage by reduce long run costs and determine their offerings from those of their competition, as a result of cheaper recyclable materials use, energy-saving processes, wasteminimization solutions, and operating process improvements. Adopting (EMS) in firms generally depends on exploring, developing, and maintaining organizational resources and capabilities together (Yu, 2011; Camison and Fores, 2015).

In general, travel agencies' and hotels' competitive advantage (as a dependent variable) in Cairo is determined by environmental marketing strategy adoption (as a moderator Variable). This environmental marketing strategy is also determined by organizational resources and capabilities (as independent variables). Study respondents perceive the six constructs of elements have a significant effect on environmental marketing strategy adoption according to the coefficient table. Experiential Resources has a significant positive impact on environmental marketing 
strategy $(\beta=0.107$ and $p<0.01)(\mathrm{H} 1)$. Furthermore, Financial Resources is found positively impact on environmental marketing strategy $(\beta=0.282$ and $\mathrm{p}<0.01)(\mathrm{H} 2)$, while Physical Resources is recorded $(\beta=0.744$ and $p<0.01)(\mathrm{H} 3)$. Technology Sensing Capability $(\beta=.137$ and $p<0.01)(\mathrm{H} 4)$. Shared Vision Capability $(\beta=0.351$ and $p<0.01)(H 5)$. Relationship building capability $(\beta=0.122$ and $\mathrm{p}<0.01)(\mathrm{H} 6)$. On the other hand, Environmental Marketing Strategy was perceived as a significant positive effect on travel agencies' and hotels' Competitive Advantages $(\beta=-0.088$ and $\mathrm{p}<0.05)$ (H7). Therefore, the seven hypotheses are statistically supported, and factors are significantly affecting travel agencies' and hotels' Competitive Advantages. These factors explain $70.1 \%$ of the variance in the effectiveness of environmental marketing strategy (R2= 0.701).

\section{Conclusion and limitations}

The purpose of this study is to investigate the effect of organizational resources and capabilities on competitive advantage through the mediating role of environmental marketing strategy within Egyptian travel agencies category " $\mathrm{A}$ " and five-star hotels in Cairo. The study has tested seven hypotheses of how these organizational resources and capabilities (experiential, financial, and physical resources; technology sensing/response, shared vision, and relationship-building capabilities) affect the mediating variable (environmental marketing strategy) and how this strategy adapted affects Egyptian hotels' and travel agencies' competitive advantage by growing trend in the tourism and hospitality market of environmentally conscious customers who appreciate agencies and hotels that care about the environment.

This study has used a quantitative approach as a method to test the study hypotheses. The procedure for collecting data for this study used a questionnaire to collect data from 297 travel agents and five-star hotel managers in Cairo, and to perceive their opinions on these resources and capabilities that lead to adopt an environmentally friendly strategic, and how this strategy affect competitive advantage. Statistical analyses were performed using software of SPSS version 22. Results of study have been considered significant at $p \leq 0.05$. Systematic random sampling was used since the subjects were selected because of their convenient accessibility and proximity. Data collection was carried out during period from November-December 2019. The study has revealed very valuable results in the way it investigated the perceptions of managers on the role of organizational resources and capabilities which lead to build EMS. Meanwhile, this mediator factor of environmental marketing strategy showed a significant positive effect on agencies' and hotels' competitive advantage approved with (Hudson and Miller, 2005; El Dief and Font, 2010; Lopez-Gamero et al., 2011b; Leonidou et al., 2013; Fraj et al., 2015; Ramanathan et al., 2016; Del Rosario et al., 2019; Morgan et al., 2019; Wang et al., 2020; Papadas et al., 2019).

Directions for further research should include conducting qualitative interviews to easily understand how organizational resources and capabilities influence environmental marketing strategy, and how this strategy affects agencies' and hotels' competitive advantage in Cairo. It would also be useful to study the effect of additional organizational resources and capabilities on building EMS such as human resources and new products development. Finally, there is a need to apply research model in other tourism and hospitality sectors such as restaurants, and catering firms or low-rated and smaller travel agencies and hotels.

\section{References}

Alt, E., Díez-de-Castro, E., Llorens-Montes, F. (2014). Linking employee stakeholders to environmental performance: the role of proactive environmental strategies and shared vision. J. Bus. Ethics 128(1), 167-181. 
Aragón-Correa, J., \& Rubio-Lopez, E. (2007). Proactive corporate environmental strategies: myths and misunderstandings. Long Range Planning, 40(3), 357-381.

Aragon-Correa, J., Hurtado-Torres, N., Sharma, S., \& García-Morales, V. (2008). Environmental strategy and performance in small firms: a resource-based perspective. Journal of Environmental Management, 86(1), 88-103.

Bae, H. S. (2017). The effect of environmental capabilities on environmental strategy and environmental performance of Korean exporters for green supply chain management. The Asian Journal of Shipping and Logistics, 33(3), 167-176.

Ball, S., \& Taleb, M. (2011). Benchmarking waste disposal in the Egyptian hotel industry. Tourism and Hospitality Research, 11(1), 1-18.

Banerjee, S. (2017). Corporate environmentalism and the greening of strategic marketing: Implications for marketing theory and practice. In Greener Marketing, Routledge, 16-40.

Beleska-Spasova, E., Glaister, K., \& Stride, C. (2012). Resource determinants of strategy and performance: The case of British exporters. Journal of World Business, 47(4), 635-647.

Bohdanowicz, P., Zientara, P., \& Novenas, E. (2011). International hotel chains and environmental protection: an analysis of Hilton's we care! Program (Europe, 2006-2008). Journal of Sustainable Tourism, 19(7), 797-816.

Botezat, E., \& Benea, C. (2012). Stimulating the Potential of Local Resources in order to achieve Competitiveness in Romanian. Tourism. Procedia Economics and Finance, 3, 1256-1261.

Buysse, K., Verbeke, A. (2003). Proactive environmental strategies: a stakeholder management perspective. Strategy. Manage. J. 24 (5), 453-470.

Camisón Zornoza, C., \& Monfort Mir, V. (2012). Measuring innovation in tourism from the Schumpeterian and the dynamic-capabilities perspectives. Tourism Management, 2012(33), 776-789.

Camisón, C., \& Forés, B. (2015). Is tourism firm competitiveness driven by different internal or external specific factors? New empirical evidence from Spain. Tourism Management, 48, 477499.

Chan, E. S. (2011). Implementing environmental management systems in small and medium-sized hotels: obstacles. Journal of Hospitality and Tourism Research, 35(1), 3-23.

Cheraghalizadeh, R., \& Tümer, M. (2017). The effect of applied resources on competitive advantage in hotels: Mediation and moderation analysis. Journal of Hospitality and Tourism Management, 31, 265-272.

Chiou, T., Chan, H., Lettice, F., Chung, S. (2011). The influence of greening the suppliers and green innovation on environmental performance and competitive advantage in Taiwan. Transp. Res. Part E: Logistics Transp. Rev. 47 (6), 822-836.

Clarkson, P., Li, Y., Richardson, G., Vasvari, F. (2011). Does it really pay to be green? Determinants and consequences of proactive environmental strategies. J. Accounting Public Policy 30 (2), 122-144.

Darnall, N., \& Edwards, D. (2006). Predicting the cost of environmental management system adoption: the role of capabilities, resources, and ownership structure. Strategic Management Journal, 27(2), 310-320.

Day, G. (2014). An outside-in approach to resource-based theories. Journal of the Academy of Marketing Science, 42(1), 27-28.

Del Rosario Reyes-Santiago, M., Sánchez-Medina, P., \& Díaz-Pichardo, R. (2019). The influence of environmental dynamic capabilities on organizational and environmental performance of hotels: Evidence from Mexico. Journal of Cleaner Production, 227, 414-423. 
Delmas, M., Hoffmann, V., \& Kuss, M. (2011). Under the tip of the iceberg: Absorptive capacity, environmental strategy, and competitive advantage. Business \& Society, 50(1), 116-154.

Dewhurst, H., \& Thomas, R. (2003). Encouraging sustainable business practices in a nonregulatory environment: a case study of small tourism firms in the UK National Park. Journal of Sustainable Tourism, 11(5), 383-403.

Dikova, D., Van Witteloostuijn, A., \& Parker, S. (2017). Capability, environment and internationalization fit, and financial and marketing performance of MNEs' foreign subsidiaries: An abductive contingency approach. Cross Cultural \& Strategic Management, 24(3), 405-435.

Dodd, M. D. (2016). Intangible resource management: social capital theory development for public relations. Journal of Communication Management, 20(4), 289-311.

Doody, H. (2010). What are the barriers to implementing environmental practices in the Irish hospitality industry? In: Tourism and Hospitality Research in Ireland Conference (THRIC).

Dzhandzhugazova, E. A., Zaitseva, N. A., Larionova, A. A., \& Pervunin, S. N. (2015). The Russian Hotel Market: condition and development under the crisis. Mediterranean Journal of Social Sciences, 6(3 S5), 289-296.

Eisenhardt, K. M., \& Martin, J. A. (2000). Dynamic capabilities: what are they? Strategic Management Journal, 21(10-11), 1105-1121.

El Dief, M., \& Font, X. (2010). The determinant of hotel's marketing managers green marketing behavior. Journal of Sustainable Tourism, 18(2), 157-174.

Erdogan, N., \& Baris, E. (2007). Environmental protection programs and conservation practices of hotels in Ankara, Turkey. Tourism Management, 28(2), 604-614.

Evans, N. (2015). Strategic management for tourism, hospitality and events. Abingdon UK \& New York USA: Routledge.

Evans, N. G. (2016). Sustainable competitive advantage in tourism organizations: A strategic model applying service dominant logic and tourism's defining characteristics. Tourism Management Perspectives, 18, 14-25.

Farias, S. A., Aguiar E. C., \& Melo, F. S. (2014). Store atmospherics and experiential marketing: A conceptual frame work and research propositions for an extraordinary customer experience. International Business Research, 7(2), 87-99.

Ferreira, J., Coelho, A., \& Moutinho, L. (2018). Dynamic capabilities, creativity and innovation capability and their impact on competitive advantage and firm performance: The moderating role of entrepreneurial orientation. Technovation, 92-93, https://doi.org/10.1016/j.technovation.2018.11.004

Fraj, E., Matute, J., \& Melero, I. (2015). Environmental strategies and organizational competitiveness in the hotel industry: the role of learning and innovateion as determinants of environmental success. Tourism Management, 46, 30-42.

Galbreath, J. (2005). Which resources matter the most to firm success? An exploratory study of resource-based theory. Technovation, 25(9), 979-987

Gambardella, A., \& Giarratana, M. S. (2013). General technological capabilities, product market fragmentation, and markets for technology. Research Policy, 42(2), 315-325.

Garay, L., \& Font, X. (2012). Doing good to do well? Corporate social responsibility reasons, practices, and impacts in small and medium accommodation enterprises. International Journal of Hospitality Management, 31(2), 329-337. 
Gil-Padilla, A. M., \& Espino-Rodríguez, T. F. (2008). Strategic value and resources and capabilities of the information systems area and their impact on organizational performance in the hotel sector. Tourism Review, 63(3), 21-47.

Greco, M., Cricelli, L., \& Grimaldi, M. (2013). A strategic management framework of tangible and intangible assets. European Management Journal, 31(1), 55-66.

Gu, J. W., \& Jung, H. W. (2013). The effects of are resources, capabilities, and qualities on organizational performance: An integrated approach. Information \&Management, 50(2e3), 8797

Gulati, R. (2010). Reorganize for resilience: Putting customers at the center of your business. Harvard Business Press.

Guo, H., Xu, H., Tang, C., Liu-Thompkins, Y., Guo, Z., \& Dong, B. (2018). Comparing the impact of different marketing capabilities: Empirical evidence from B2B firms in China. Journal of Business Research, 93, 79-89.

Hall, J.K., Daneke, G.A., Lenox, M.J. (2010). Sustainable development and entrepreneurship: past contributions and future directions. J. Bus. Venturing 25 (5), 439-448.

Hall, R. (2006). A framework linking intangible resources and capabilities to sustainable competitive advantage. Strategic Management Journal, 14(8), 607-618.

Hart, S.L., Dowell, G., 2011. Invited editorial: a natural-Resource-Based view of the Firm: Fifteen years after. J. Manage. 37 (5), 1464-1479.

Horng, J. S., Liu, C. H., Chou, S. F., Tsai, C. Y., \& Chung, Y. C. (2017). From innovation to sustainability: Sustainability innovations of eco-friendly hotels in Taiwan. International Journal of Hospitality Management, 63, 44-52.

Hsiao, T., Chuang, C., Kuo, N., \& Yu, S. M. (2014). Establishing attributes of an environmental management system for green hotel evaluation. International Journal of Hospitality Management, 36,197-208.

Hsieh, Y. (2012). Hotel companies' environmental policies and practices: a content analysis of their web pages. International Journal of Contemporary Hospitality Management, 24(1), 97121

Hudson, S., \& Miller, G. A. (2005). The responsible marketing of tourism: the case of Canadian mountain holidays. Tourism Management, 26(2), 133-142.

Kaleka, A. (2002). Resources and capabilities driving competitive advantage in export markets: guidelines for industrial exporters. Industrial Marketing Management, 31(3), 273-283.

Kasim, A. (2009). Managerial attitudes towards environmental management among small and medium hotels in Kuala Lumpur. Journal of Sustainable Tourism, 17(6), 709-725.

Kasim, A., Gursoy, D., Okumus, F., \& Wong, A. (2014). The importance of water management in hotels: a framework for sustainability through innovation. Journal of Sustainable Tourism, 22(7), 1090-1107.

Kotler, P., \& Lee, N. R. (2008). Social marketing: Influencing behaviors for good (3rd Ed.). Thousand Oaks, CA: Sage.

Kousis, M. (2000). Tourism and the environment: a social movements perspective. Annals of Tourism Research, 27(2), 468-489.

Leonidou, C. N., Katsikeas, C. S., \& Morgan, N. A. (2013a). "Greening” the marketing mix: Do firms do it and does it pay off? Journal of the Academy of Marketing Science, 41(2), 151-170.

Leonidou, L., Fotiadis, T., Christodoulides, P., Spyropoulou, S., \& Katsikeas, C. (2015a). Environmentally friendly export business strategy: Its determinants and effects on competitive advantage and performance. International Business Review, 24(5), 798-811. 
Leonidou, L., Leonidou, C., Fotiadis, T., \& Aykol, B. (2015b). Dynamic capabilities driving an eco-based advantage and performance in global hotel chains: The moderating effect of international strategy. Tourism Management, 50, 268-280.

Leonidou, L., Leonidou, C., Fotiadis, T., \& Zeriti, A. (2013b). Resources and capabilities as drivers of hotel environmental marketing strategy: Implications for competitive advantage and performance. Tourism Management, 35, 94-110.

López-Gamero, M., Claver-Cortés, E., \& Molina-Azorin, J. (2011a). Environmental perception, management, and competitive opportunity in Spanish hotels. Cornell Hospitality Quarterly, 52(4), 480-500.

López-Gamero, M., Molina-Azorín, J., \& Claver-Cortes, E. (2011b). The relationship between managers' environmental perceptions, environmental management and firm performance in Spanish hotels: a whole framework. International Journal of Tourism Research, 13(2), 141163.

McDonagh, P., \& Prothero, A. (2014). Sustainability marketing research: Past, present and future. Journal of Marketing Management, 30(11-12), 1186-1219.

Menguc, B., Auh, S., \& Ozanne, L. (2010). The interactive effect of internal and external factors on a proactive environmental strategy and its influence on afirm's performance. Journal of Business Ethics, 94(2), 279-298.

Mol, J. M., \& Wijnberg, N. M. (2011). From resources to value and back: Competition between \& within organizations. British Journal of Management, 22(1), 77-95.

Morgan, N. A., Katsikeas, C. S., \& Vorhies, D. W. (2012). Export marketing strategy implementation, export marketing capabilities, and export venture performance. Journal of the Academy of Marketing Science, 40(2), 271-289.

Morgan, N., Zou, S., Vorhies, D., Katsikeas, C. (2004). Experiential and informational knowledge, architectural marketing capabilities, and the adaptive performance of export ventures. Decis. Sci. 34 (2), 287-321.

Morgan, R., Miočević, D., \& Herhausen, D. (2019). Capability-driven industrial firms: Considering resources, capabilities, and competencies for marketing developments. Industrial Marketing Management, 83, 1-7.

Neill, S., Singh, G., \& Pathak, R. D. (2014). Technology and marketing capabilities in a developing economic context: assessing the resource-based view within a boundary condition. International Journal of Business and Economics, 13(1), 75-92.

Newbert, S. L. (2008). Value, rareness, competitive advantage, and performance: a conceptuallevel empirical investigation of the resource-based view of the firm. Strategic Management Journal, 29(7), 745-768.

Nieves, J., \& Haller, S. (2014). Building dynamic capabilities through knowledge resources. Tourism Management, 40, 224-232.

Nisbet, E., Zelenski, J., \& Murphy, S. (2009). The nature relatedness scale- linking individuals' connection with nature to environmental concern and behavior. Environment and Behavior, 41(5), 715-740.

O'Cass, A., \& Weerawardena, J. (2010). The effects of perceived industry competitive intensity and marketing-related capabilities: Drivers of superior brand performance. Industrial Marketing Management, 39(4), 571-581.

Olavarrieta, S., \& Friedmann, F. (2008). Market orientation, knowledge-related resources and firm performance. Journal of Business Research, 61(6), 623-630. 
Ong, T., \& Musa, G. (2012). SCUBA divers' underwater responsible behaviour: Can environmental concern and divers' attitude make a difference? Current Issues in Tourism, 15(4), 329-351.

Ortega, M. J. (2010). Competitive strategies and firm performance: Technological capabilities' moderating roles. Journal of Business Research, 63(12), 1273-1281.

Ottenbacher, M. (2007). Innovation management in the hospitality industry: different strategies for achieving success. J. Hosp. Tour. Res. 31 (4), 431-454.

Papadas, K. K., Avlonitis, G. J., \& Carrigan, M. (2017). Green marketing orientation: Conceptualization, scale development and validation. Journal of Business Research, 80, 236246.

Papadas, K. K., Avlonitis, G. J., Carrigan, M., \& Piha, L. (2019). The interplay of strategic and internal green marketing orientation on competitive advantage. Journal of Business Research, $104,632-643$.

Qoura, O. E., \& Ali, E. (2015). Energy Saving and Green Practices in the Cairo Five-Star Hotels: An Exploratory Study. International Journal of Heritage, Tourism, and Hospitality, 9 (1),

Ramanathan, R., Ramanathan, U., \& Zhang, Y. (2016). Linking operations, marketing and environmental capabilities and diversification to hotel performance: A data envelopment analysis approach. International Journal of Production Economics, 176, 111-122.

Ramanathan, U., \& Ramanathan, R. (2013). Investigating the impact of resource capabilities on customer loyalty: a structural equation approach for the UK hotels using online ratings. Journal of Services Marketing, 27(5), 404-415.

Ramaswami, S., Srivastava, R., \& Bhargava, M. (2009). Market-based capabilities and financial performance of firms: insights into marketing's contribution to firm value. Journal of the Academy of Marketing Science, 37(2), 97-116

Ray, G., Barney, J. B., \& Muhanna, W. A. (2004). Capabilities, business processes, and competitive advantage: choosing the dependent variable in empirical tests of the resourcebased view. Strategic Management Journal, 25(1), 23-37.

Ren, S., Eisingerich, A., Tsai, H., (2015). How do marketing, research and development capabilities, and degree of internationalization synergistically affect the innovation performance of small and medium-sized enterprises (SMEs)? A panel data study of Chinese SMEs. Int. Bus. Rev. 24, 642-651.

Robin, C. F., Pedroche, M. S. C., \& Astorga, P. S. (2017). Revisiting green practices in the hotel industry: A comparison between mature and emerging destinations. Journal of cleaner production, 140, 1415-1428.

Rodriguez-Diaz, M., \& Espino-Rodriguez, T. (2006). Developing relational capabilities in hotels. International Journal of Contemporary Hospitality Management, 18(1), 25-40.

Royne, M., Levy, M., \& Martinez, J. (2011). The public health implications of consumers' environmental concern and their willingness to pay for an ecofriendly product. Journal of Consumer Affairs, 45(2), 329-343.

Sánchez-Medina, P. S., Díaz-Pichardo, R., \& Cruz-Bautista, M. (2016). Stakeholder influence on the implementation of environmental management practices in the hotel industry. International Journal of Tourism Research, 18(4), 387-398.

Shaalan, I. M. (2005). Sustainable tourism development in the Red Sea of Egypt threats and opportunities. Journal of Cleaner Production, 12(2), 83-87

Shah, K. U. (2011). Strategic organizational drivers of corporate environmental responsibility in the Caribbean hotel industry. Policy Sciences, 44,321-344. 
Sharma, S., Aragón-Correa, J. A., \& Rueda-Manzanares, A. (2007). The contingent influence of organizational capabilities on proactive environmental strategy in the service sector: an analysis of North American and European ski resorts. Canadian Journal of Administrative Sciences, 24(4), 268-283.

Singjai, K., Winata, L., \& Kummer, T. (2018). Green initiatives and their competitive advantage for the hotel industry in developing countries. International Journal of Hospitality Management, 75, 131-143.

Tan, K. C., Kannan, V. R., \& Narasimhan, R. (2007). The impact of operations capability on firm performance. International Journal of Production Research, 45(21), 5135-5156.

Tsai, H., Song, H., \& Wong, K. (2009). Tourism and hotel competitiveness research. Journal of travel \& tourism marketing, 26(5-6), 522-546.

Tzschentke, N., Kirk, D., \& Lynch, P. (2008). Going green: decisional factors in small hospitality operations. International Journal of Hospitality Management, 27(1), 126-133.

Verreynne, M., Hine, D., Coote, L., \& Parker, R. (2016). Building a scale for dynamic learning capabilities: The role of resources, learning, competitive intent and routine patterning. Journal of Business Research, 69(10), 4287-4303.

Vorhies, D., \& Morgan, N. (2005). Benchmarking marketing capabilities for sustainable competitive advantage. Journal of Marketing, 69(1), 80-94.

Wang, C., \& Ahmed, P. (2007). Dynamic capabilities: A review \& research agenda. International Journal of Management Reviews, 9(1), 31-51.

Wang, Y., Font, X., \& Liu, J. (2020). Antecedents, mediation effects and outcomes of hotel ecoinnovation practice. International Journal of Hospitality Management, 85, https://doi.org/10.1016/j.ijhm.2019.102345

Weerawardena, J., \& Mavondo, F. (2011). Capabilities, innovation and competitive advantage. Industrial Marketing Management, 40(8), 1220-1223.

Welter, C., Bosse, D., \& Alvarez, S. (2013). The interaction between managerial and technological capabilities as a determinant of company performance: An empirical study of biotech firms. International Journal of Management, 30(1), 272.

Yasuo, O., Shinichi, K. and Shimpei, S. (2010). Evaluating linkage between operators 'satisfaction and potential of local resources for rural tourism, Applied Studies In Agribusiness and Commerce, Vol. 4. Numbers 1-2, pp. 33-41.

Yin-Hsi, L. (2012). Managerial capabilities, organizational culture and organizational performance: the resource-based perspective in Chinese lodging industry. J. Int. Manage. Stud. 7 (1), 151-157.

Yu, C. P. (2011). Sensory marketing. Managing Service Quality: An International Journal, 21(5), 568-570. 